\title{
Online Learning System for Kampus Merdeka : Innovative Learning In Covid-19 Pandemic
}

\author{
Budi Harijanto ${ }^{1}$, Meyti Eka Apriyani ${ }^{2}$, Elok Nur Hamdana ${ }^{3}$ \\ 1,2,3 Department Technology Information State Polytechnic of Malang, Malang, Indonesia
}

\begin{tabular}{|c|c|}
\hline (A) Check for updates open 2 access (c) (i) () & DOI : https://doi.org/10.46245/ijorer.v2i5.156 \\
\hline Sections Info & ABSTRACT \\
\hline $\begin{array}{l}\text { Article history: } \\
\text { Submitted: August 31, } 2021 \\
\text { Final Revised: September 15, } 2021 \\
\text { Accepted: September 27, } 2021 \\
\text { Published: September 30, } 2021\end{array}$ & $\begin{array}{l}\text { Innovations in learning media for "Kampus Merdeka" currently require } \\
\text { students active roles in online lectures and interact with lecturers and } \\
\text { college friends to be able to use social networking media. Massive Online } \\
\text { Open Course (MOOC) is web-based learning that can be accessed } \\
\text { anywhere and anytime by integrating technology into the learning process }\end{array}$ \\
\hline $\begin{array}{l}\text { Keywords: } \\
\text { Kampus Merdeka } \\
\text { MOOC } \\
\text { Online Learning } \\
\text { Web Programming }\end{array}$ & $\begin{array}{l}\text { that can help improve understanding of the material. In this reasearch an } \\
\text { online learning design using MOOC as a solution in the implementation of } \\
\text { "Kampus Merdeka" using Web Programming Design course. The reason } \\
\text { for choosing these subjects is because practical learning activities require an } \\
\text { understanding of a strong theoretical basis. Learning Outcomes in this }\end{array}$ \\
\hline$\frac{8}{8}$ & $\begin{array}{l}\text { course are students can understand the basics and concepts in website } \\
\text { before finally carrying out the practicum. In the study sample population } \\
\text { in the MOOC Web Programming course which was attended by } 30 \\
\text { students from various backgrounds, it was seen that on average } 78.2 \% \\
\text { interesting join the MOOC online class. The results of this percentage show } \\
\text { that students are interested in joining MOOC online classes because they } \\
\text { can provide a self-development model, namely institutional (materials that } \\
\text { are in accordance with the syllabus), pedagogical in the form of learning } \\
\text { videos) and technical (in the form of practicums) }\end{array}$ \\
\hline
\end{tabular}

\section{INTRODUCTION}

Currently, information and communication technology (ICT) has become a part of everyday life to fulfill needs and has not been fully exploited. The development of this technology is also one of the factors in the development of various types of learning media. The learning process that is currently developing is a learning process that does not have to attend class as usual or what is known as online learning. State Polytechnic of Malang is one of the universities based on science and technology that implements one of its online-based learning processes with learning media using web learning. In its academic activities, State Polytechnic of Malang uses e-learning media, namely the Learning Management System (Harijanto et al., 2017) In the implementation of this learning model, students must be registered in these courses according to the study program taken. Students from other study programs cannot enter courses outside the study program and cannot take part in the learning process of these courses (Sudaryanto, 2020) The basically implemented a learning system with credits that almost all require learning activities in the classroom. This shows the lack of learning independence that must be carried out by every student in carrying out their learning.

Learning outside of the "Kampus Merdeka" study program through online class taking offers students the freedom to choose a variety of materials offered from their own campus, other campuses, or from the industrial world, just from home an ideal thing to do during the COVID-19 pandemic. The best way for this institution is to provide facilities by cooperating with a platform that provides massive and open online 
classes or MOOC. The platform used to support learning system for MOOC innovation is Moodle. Moodle is a type of LMS (Learning Management System) that allows twoway communication between educators and students, has a history of activities and flexibility in use that makes it easy for students and educators to manage schedules and learning activities (Suyetno et al., 2019)

Along with technological developments, an innovation in learning emerged without having to meet face to face, but virtually. Without a clear new concept of learning methods, it is very unlikely that the fulfillment of needs will not be met with some of the obstacles that are currently happening. This innovation is called MOOC (Massive Open Online Course) or online learning. Massive Open Online Course (MOOC) is a web-based online course that attracts various people globally.

The technical presentation of the material presented in MOOC is carried out openly in an online class as an innovation in learning that connects communication between teachers and learning media such as images, text, audio and videos (Abbakumov et al., 2019) In this MOOC learning model, the learning used is exploring knowledge and gaining experience from other students, taking exams and getting certificates for exam results. However, until now learning through MOOC still has problems in maximizing the active participation of learners in learning from beginning to end (Borrás-Gené, 2019)

MOOC is defined as an online learning environment with "Kampus Merdeka" that is open and easily accessible. MOOC creates novel approach inlearning and teaching. The platform provides lecturers or more known as facilitators who facilitate the participation of the participants by engaging and interacting with the participants (You, 2019) MOOC is a web-based technology that provides online courses which can be accessed anywhere, anytime and free enrollment. It is also a recent trends in e-learning [10] MOOC can be considered as new form of e-learning that integrates social network, expert facilitation, and online learning resources. Such online learning is expected to give greater flexibility and control over the learning process (Nasri and Mydin, 2017) In developing countries, such as Indonesia, MOOC is not yet popular because there are still forms of learning in infrastructure. Examples of MOOC sites in Indonesia are IndonesiaX sites, Dicoding, Open University MOOCs etc. In the programming field, MOOC programming has become one of the most popular and also accommodates a lot of data. This is because many store assignments and forum results that contain coding and various kinds of solutions for students. Even so, it is still necessary to provide features such as feedback for program functional results and syntax based on program structure. Currently, one of the Ministry of Education and Culture's programs is the Independent Learning or Kampus Merdeka policy which gives students freedom and autonomy to choose their preferred field (courses) outside/in the study program/campus. This freedom and autonomy is a right for every student (can take it or not) however, universities (PT) are obliged to facilitate it.

Pedagogy is the science or art of being a teacher. This term refers to learning strategies or learning styles. The main purpose of this research is to provide input to campuses to design new approaches to online learning systems that can support "Kampus Merdeka", one of which is MOOC. Students can be more flexible to study according to their interests and talents. MOOC based on web learning can be used as a solution in online learning media during a pandemic. In this research, the desired result is MOOC which can provide learning media development models and credit knowledge models that can be included at the end of MOOC implementation. 
The subject that will be implemented in the development of learning system MOOC innovation is the Web Programming Design course for the Kampus Merdeka from informatic management study program State Polytechnic of Malang. The reason for choosing these subjects is because practical learning activities require an understanding of a strong theoretical basis, without an understanding of the theoretical basis, what will be done during the practicum. This study aims to provide one of the innovations and strategies for students in the learning method of learning on the implementation of an independent campus during the covid-19 pandemic which can include a selfdevelopment model, namely institutional (material that is in accordance with the syllabus), pedagogical in the form of learning videos) and technical

\section{RESEARCH METHOD \\ General Background}

This research is a type of research and development Research and Development (R\&D), which is applied to produce certain products, and test the effectiveness of the products produced (Sugiyono, 2016). With the aim of developing online learning model for Kampus Merdeka used ADDIE Model. The ADDIE model in development research consists of five stages of development, namely: Analysis, Design, Development, Implementation and Evaluation.

\section{Sample / Participants / Group}

The research subject is the development of the Merdeka Campus online learning model. At the research sample population stage who took the MOOC Web Programming course which was attended by 30 students from various backgrounds outside the field of information technology who had taken basic information technology courses

\section{Data Analysis}

At this stage, the analysis stage is the beginning of the learning media development process. This process involves several processes of determining and identifying problems that need to be resolved. By conducting various analyzes, problems that can be identified will appear which will be the basis for developing learning media. In the analysis phase of the ADDIE model according to Lee and Owens, the analysis process separates the learning design analysis phase into two parts, namely needs analysis and final result analysis. The analysis process includes the problems encountered, product requirements include product development objectives.
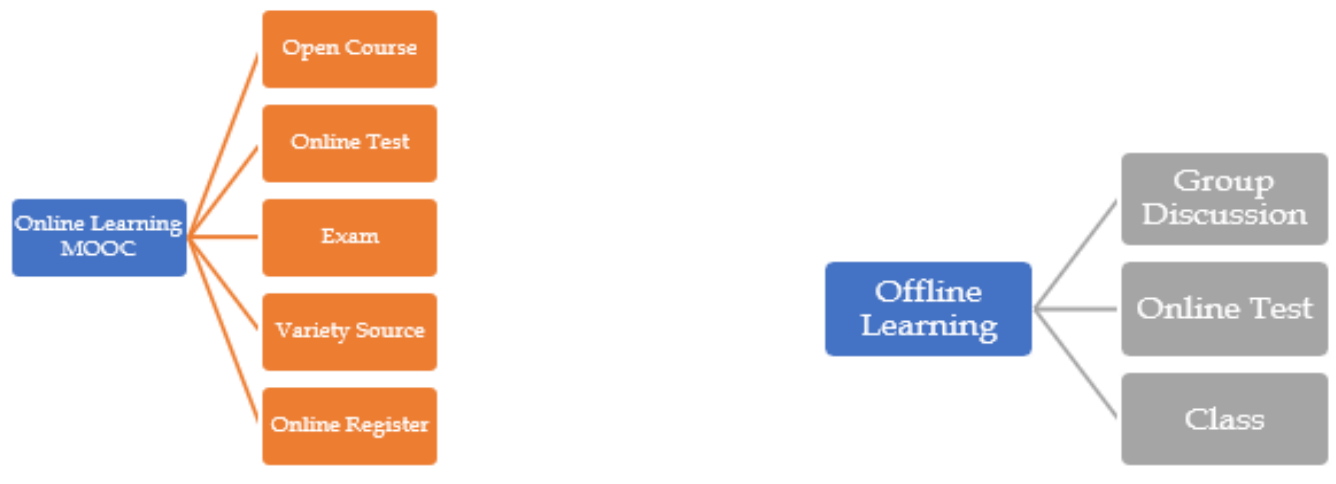

Figure 1. Kampus merdeka integrating MOOC. 
There is a difference between online and offline learning systems. For online learning focuses on MOOC principles. Online MOOC focuses on implementing an Kampus Merdekathat focuses on online courses, exams, online tests and online registers. Offline MOOC focuses on group discussion, class, offline test. The technical features contained in online learning MOOC are that the open course is available during course selection and course registration, the online test is opened when the exam takes place on the application, the exam can display results directly on each selected course. For offline learning, the implementation is in the form of forums or discussion groups that can be accessed at any time.

The implementation of the Kampus Merdeka for MOOC being used as a learning medium during this pandemic as a substitute for face-to-face media conducted by lectures. Students will participate both in lectures and tutorials in classrooms as well as online learning in MOOC. The topics in the course Pemrograman Web syllabus is shown in Table 1. These online videos, quizzes and activities allow students to have self-paced and self-gauged learning.

Table 1. Pemrograman web syllabus.

\begin{tabular}{cc}
\hline Topic & Name \\
\hline $\mathbf{1}$ & HTML \\
$\mathbf{2}$ & CSS \\
3 & Javascript \\
$\mathbf{4}$ & Jquery \\
5 & PHP \\
6 & Database \\
7 & Session and Cookies \\
8 & Form \\
\hline
\end{tabular}

Figure 2. The concept of a MOOC was first introduced by Stephen Downes and George Siemens in 2008 as they were building a course offered by the University of Manitoba. The course's name was Connectivist and Connective Knowledge [4]

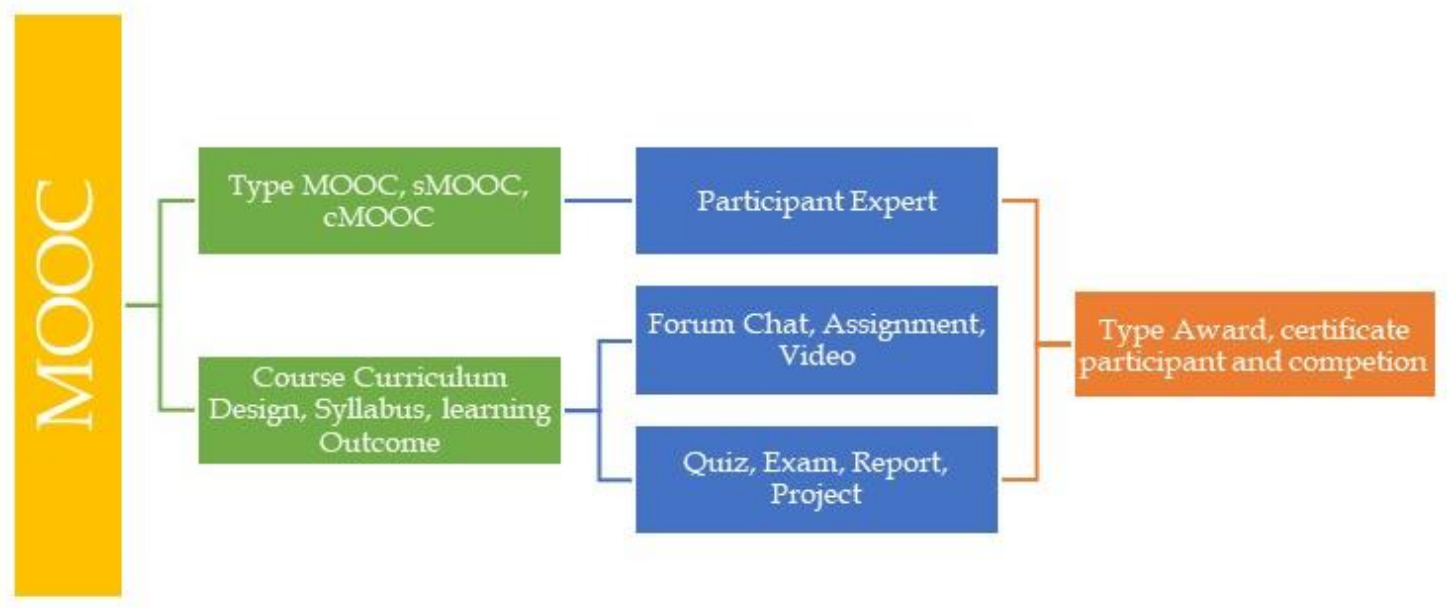

Figure 2. MOOC design.

\section{Design Phase}

This stage determines all goals, tools to be used to gauge performance, various tests, subject matter analysis, planning and resources. In the design phase, the focus is on learning objectives, content, subject matter analysis, exercise, lesson planning, 
assessment instruments used and media selection. The design phase outlines the development plan and strategies used for MOOC and it has six activities. The activities involved are design MOOC interface using moodle, providing content of each topic, designing and for each topic, submitting preparing activities for each topic for student self-assessmen.

\section{Development Phase}

At this stage of the process explain the overall picture of the design, structure, teaching approach, types of media and technology to be used, content and script/storyboard.The design stage is the planning stage of the learning media project that will be developed. The purpose of the design phase is to verify the desired results and the appropriate testing method. At this stage it is very important to plan strategies in developing teaching and outlining how to achieve teaching goals. Planning is the most important factor in the successful development of learning media.

\section{Implementation}

In the implementation phase, the uploaded learning videos are being tested on MOOC. Videos are viewed in terms of content validity, video smoothness and graphical appropriateness by field experts in order for any deficiencies to be resolved. Students were asked to do activities in each topic and assess their level of understanding and to see the effectiveness of MOOC in fulfilling their learning needs.

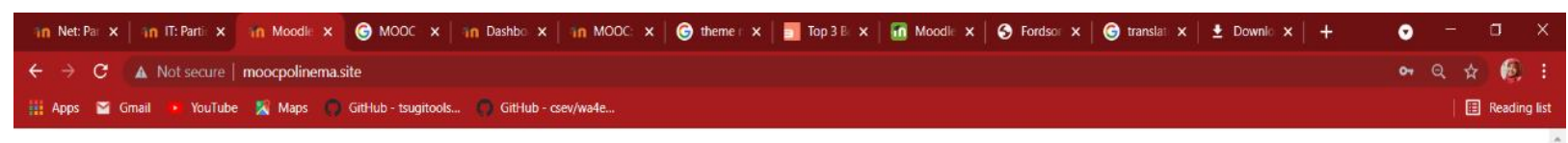

Moodle Site

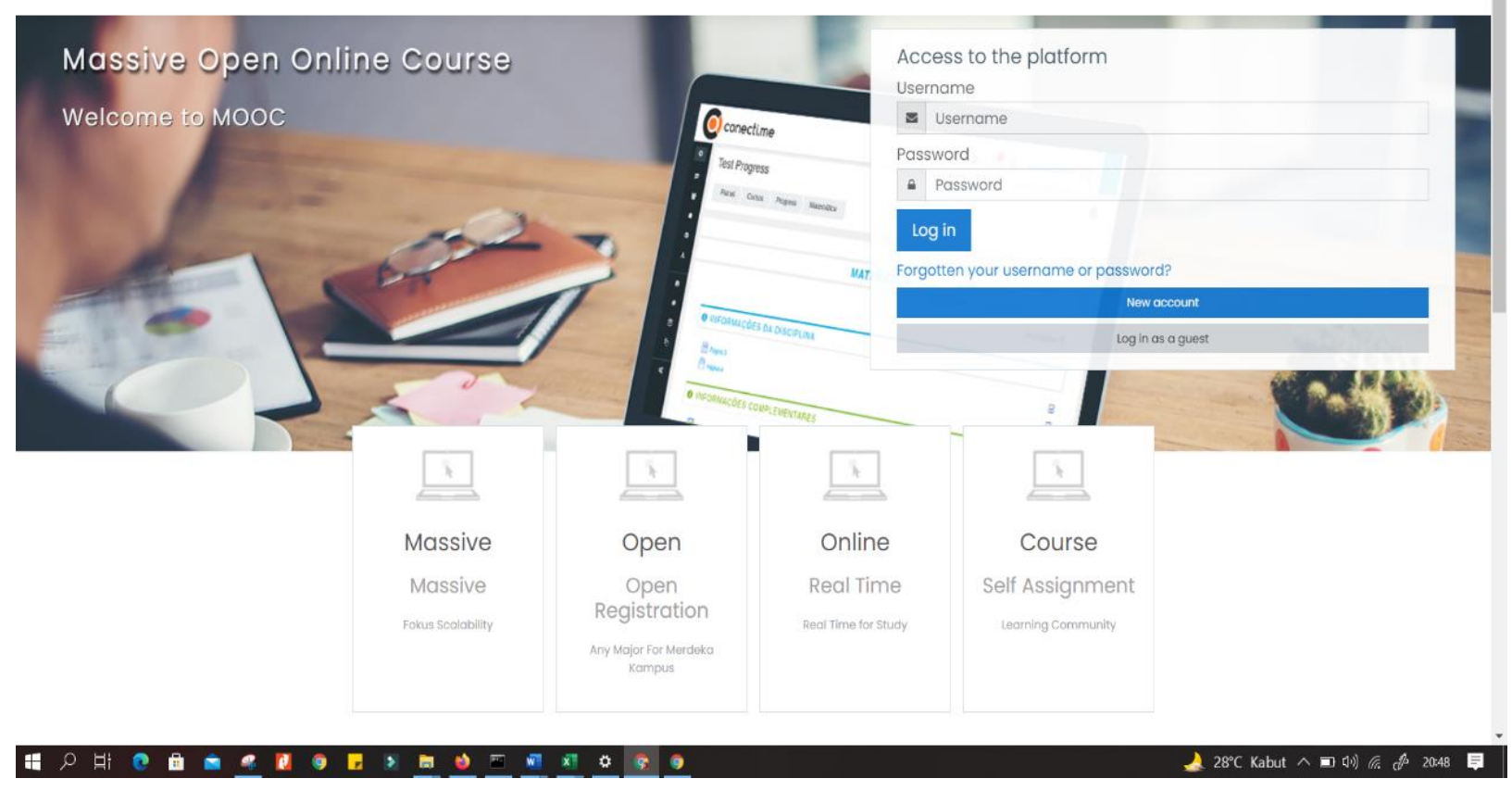

Figure 3. MOOC pemrograman web frontend.

Figure 3 shows the MOOC user interface of Pemrograman Web Frontend. The implementation of the ADDIE method lies in how to use the menu on the MOOC for students to view material and upload documents according to the agreed material. The goal is to know the improvement, feasibility, and evaluation of the application that has 
been made by the author. So that there is feedback given from experts, teachers, and students so that the application can continue to run and develop according the function. "Merdeka Belajar" to learn is to give freedom and autonomy to educational institutions, and freedom from bureaucratization, lecturers are freed from complicated bureaucracy and students are given the freedom to choose the fields they like. (Nadiem Makarim Minister of Education and Culture). The above opinion is an independent learning concept that aims to give students the freedom to studying outside the campus.

The purpose of this activity is as an effort to get qualified future leaders. One of the policies of the Kampus Merdekais the right to study three semesters outside the study program which has the aim of increasing the competence of graduates, both soft skills and hard skills to be more prepared and relevant to the needs of the times, preparing graduates as leaders of the nation with superior and personality.

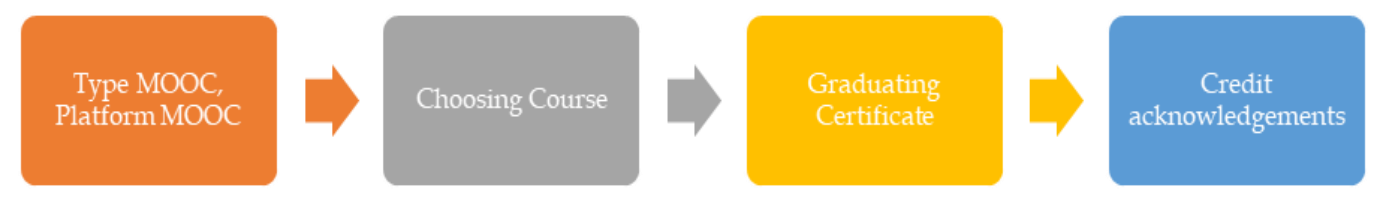

Figure 4. Credit acknowledge.

New learning that can be an innovation in the implementation of independent learning which aims to develop knowledge and skills that can make students independent, take courses according to the desired topic for learning media innovation that offers an online and open course that can be offered by many organizers is called with MOOCs. Present to provide solutions that can overcome these gaps, the presence of this model course is a positive reaction to the needs and problems of learning in the digital era, making it easier for learners to maximize their knowledge and learning experience. The main challenge of MOOC is the problem of scalability of feedback and support from MOOC users who easily decide to leave MOOC membership at any time.

The non-formal character of MOOC greatly influences and causes the result of uncommitted behavior from students. The factor of taking part in the institution or government in providing MOOC facilities is very important and greatly affects the success of the MOOC program in Indonesia.

One implementation of the use of MOOC in an Kampus Merdeka where there is a MOOC model that can be managed by universities where students from universities can take certain courses with credit weights. After students take the MOOC online and are declared to have passed, the graduation will be entered into the assessment system without having to re-take the course at the original university / major. The Fig.5 above explains that in order to get credit score recognition, students have to get a graduation certificate from the course they are taking.

\section{Evaluation}

At this stage, testing the web-based application to media experts and material experts to test the feasibility of the application by providing an instrument questionnaire. And tested on MOOC participants and lecturers to find out the response to the MOOC application by providing an instrument questionnaire that will get the conclusion of data analysis from the results of the questionnaire. 


\section{RESULTS AND DISCUSSION}

Thomas et al According to the population is the research target group where the results will be generalized. The population in this study were 30 students who took part in the Sampling program, which were respondents who were selected to represent a population. The sampling method used is purposive sampling consisting of second year students who have taken basic courses in each major.

The questionnaires were distributed online with a google form via social media. The questions in the questionnaire were designed with 8 questions using a Likert scale with a scale ranging from $0=$ 'strongly disagree' to $4=$ 'strongly agree'. There are as many as 30 respondents with different majors with students outside the Information Technology study program.

Data analysis is done by determining the average (mean) of each item, and determining the mean item in one category. Then the value is converted into percent (\%) by dividing it by the maximum value of the range 4 multiplied by $100 \%$ (Suyetno et al., 2019). To be able to give the meaning of the percentage results, an assessment classification adapted from (Suyetno et al., 2019) is used which is presented in Table 2

Table 2. Validity Criteria

\begin{tabular}{cc}
\hline Percentage & Validity \\
$75.01 \%-100 \%$ & Very Satisfied \\
$50.01 \%-75.00 \%$ & Satisfied \\
$25.01 \%-50.00 \%$ & Enough \\
$00.00 \%-25.00 \%$ & Not satisfied \\
\hline
\end{tabular}

MOOC users consist of several students who take online courses on the Merdeka Campus Web Programming. Students consist of civil engineering, electrical engineering, mechanical engineering, accounting and marketing management. The largest percentage is followed by accounting students.

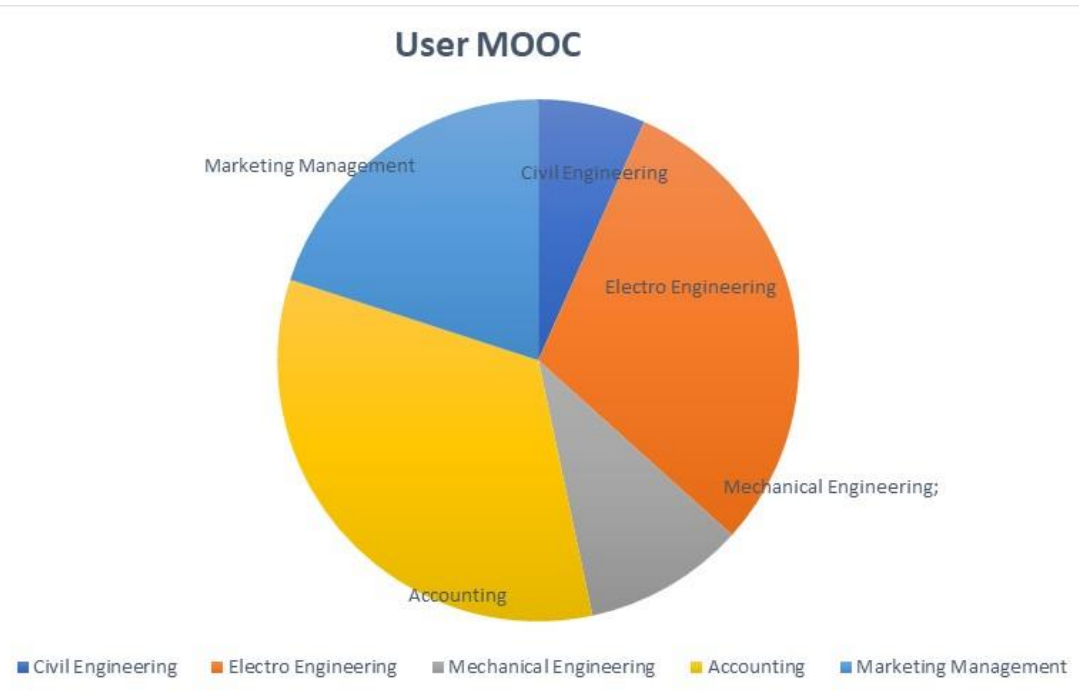

Figure 5. User MOOC.

Activities carried out by students in the use of MOOCs are used as one of the supporting indicators to support the use of MOOCs. Student activities in MOOC are login, logout, assignment collection and discussion which is presented in Figure 6. 


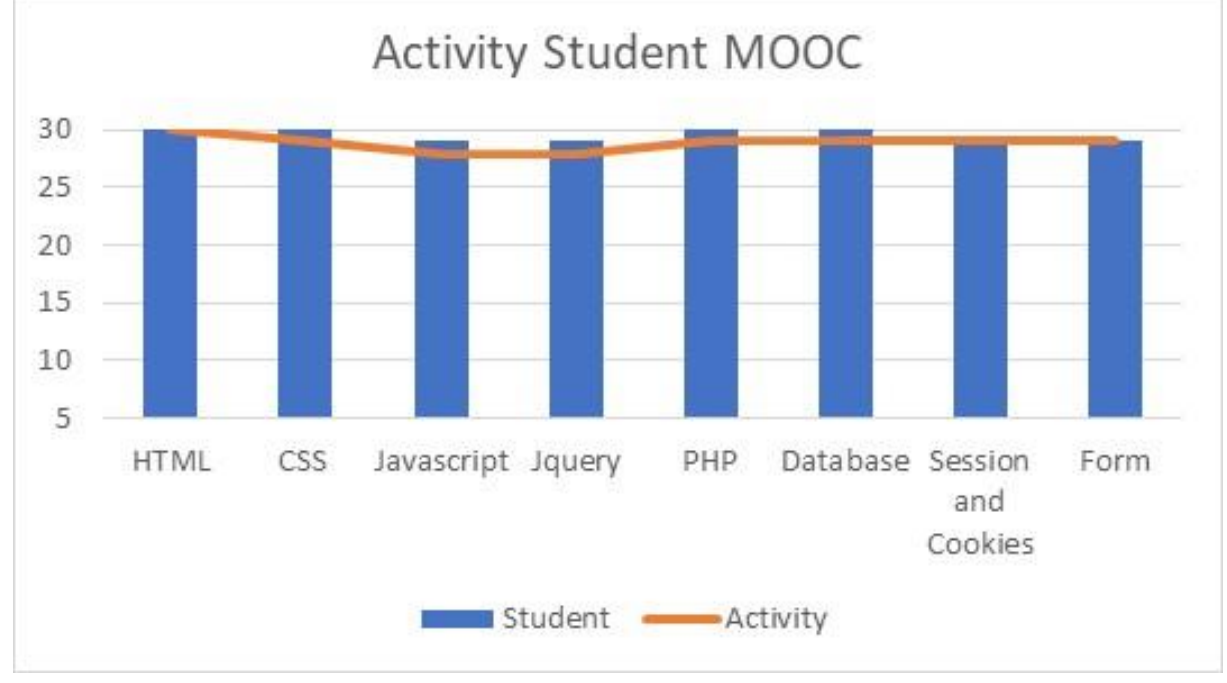

Figure 6. Activity student MOOC.

From the activities above, it can be seen that learning innovation shows student responses to the use of MOOC. The percentage in each module in the MOOC Web programming shows the percentage of $97 \%$ for students participating in module activities.

The next indicator of the effectiveness of using MOOC is students response. After the questionnaire was conducted, 30 students outside the information technology department who had used MOOC Web programming were asked to fill out a response questionnaire. Student responses were obtained based on a response questionnaire via an online google form. The results of the student response questionnaire analysis after using MOOC web programming can be seen in the following table 3 . The results of this trial were conducted to determine student perceptions of the use of MOOC.

Table 3. Student response using MOOC.

\begin{tabular}{clcc}
\hline No & \multicolumn{1}{c}{ Question } & Average & Percentage \\
\hline $\mathbf{1}$ & What is the learning platform used appropriate? & 3.05 & $76.3 \%$ \\
\hline $\mathbf{2}$ & What do lectures use MOOC for learning? & 3.17 & $79.4 \%$ \\
\hline $\mathbf{3}$ & $\begin{array}{l}\text { What are the questions contained in MOOC as a } \\
\text { learning platform? }\end{array}$ & 3.17 & $79.4 \%$ \\
\hline $\mathbf{4}$ & What do you use a learning platform for all subjects? & 3.16 & $79.1 \%$ \\
\hline $\mathbf{5}$ & What can MOOC be used at any time? & 3.16 & $79.1 \%$ \\
\hline $\mathbf{6}$ & $\begin{array}{l}\text { What do you always take advantages of learning } \\
\text { opportunities using MOOC? }\end{array}$ & 3.05 & $77.9 \%$ \\
\hline $\mathbf{7}$ & What do you often use MOOC to get material? & 3.12 & $76.4 \%$ \\
\hline $\mathbf{8}$ & What can using MOOC stimulate learning? & 3.13 & $78.1 \%$ \\
\hline
\end{tabular}

The results showed that the average score was $78.2 \%$. It means that the correspondents expressed satisfaction in using MOOC learning media. The use of the learning platform, namely Moodle, is believed to be able to provide input on one of the platforms used for MOOC with 79.4\% support for respondents. Lecturers or teachers fully use MOOC for learning platform media containing videos, tutorials and quizzes 
on the platform as much as 79.1\%. Respondents answered $79.1 \%$ for the use of MOOC which can be used for all media subjects, namely videos, files, etc. MOOC can be used at any time and take advantage of the opportunity to learn using MOOC with $77.9 \%$ of respondents. The results of this percentage show that students are interested in joining MOOC online classes because they can provide a self-development model, namely institutional (materials that are in accordance with the syllabus), pedagogical in the form of learning videos and technical (in the form of practicums).

MOOC can be used to share material and can stimulate online learning. It can be seen that the average respondent stated that their interest in the MOOC platform was that MOOC would later be implemented as a learning medium for "Merdeka Belajar". Suggestions from the results of student respondents are that the innovative use of MOOC as a learning media can allow for a new learning system that can include a selfdevelopment. The purpose of this research is successful because MOOC is a solution in online learning design where this learning can create because they can provide a selfdevelopment model, namely institutional (materials that are in accordance with the syllabus), pedagogical in the form of learning videos) and technical (in the form of practicums) (Bali, 2014).

\section{CONCLUSIONS}

Based on the results of the research above, the basic thing that can be used as a solution in learning innovation during the COVID-19 pandemic is to use Massive open online courses (MOOC). The development of this MOOC is proven to be able to support web programming practicum activities, this can be seen from student respondents. The results show that MOOC can provide a self-development model, namely an institutional system that can be in the form of material that is in accordance with the lecture syllabus, pedagogical in the form of learning videos, online tests, and exams as well as technical (in the form of practicum). Based on the results of the questionnaire, it was found that the MOOC used had a high level of feasibility with a percentage of $78.2 \%$. The ease of using MOOC can be seen from students who get a certificate of graduation from Web programming courses. The limitations contained in this study are the use of MOOC is only limited to one basic programming course and the assessment is made based on the perceptions of students who use Web programming MOOC. Further research can implement MOOC for all other courses and in accordance with the Kampus Merdeka criteria.

\section{REFERENCES}

Abbakumov, D., Desmet, P., \& Noortgate, W. V. (2019). Measuring growth in students' proficiency in MOOCs: Two component dynamic extensions for the Rasch model. Behavior Research Methods, 51(1), 332-241. https://doi.org/10.3758/s13428-018-1129-1

Bali, M. (2014). MOOC pedagogy: Gleaning good practice from existing MOOCs. MERLOT Journal of Online Learning and Teaching, 10(1), 44-56.

Borrás-Gené, O. (2019). Empowering MOOC participants: Dynamic content adaptation through external tools. Computer Science. https:/ / doi.org/10.1007/978-3-030-19875-6_14

Harijanto, B., Kusbianto, D., \& Nova, B. P. (2017). pengembangan sistem informasi proses belajar mengajar online dengan menggunakan metode pembelajaran student centered learning (SCL). JIP: Jurnal Informatika Polinema, 4(1), 17-28. https://doi.org/10.33795/jip.v4i1.139 
Nasri, N. M., \& Mydin, F. K. (2017). University students' view of self-directed learning in an online learning context. Social Sciences Research Journal,4(24), 95-102. http:/ / doi.org/10.14738/assrj.424.3994

Sudaryanto, Widayati, W., \& Amalia, R. (2020). Konsep merdeka belajar-kampus merdeka dan aplikasinya dalam pendidikan bahasa (dan sastra) Indonesia. Kode: Jurnal Bahasa, 9(2), 7893. https:// doi.org/10.24114/kjb.v9i2.18379

Sugiyono. (2016). Metode penelitian kuantitatif, kualitatif dan RED. Bandung: PT.Alfabet

Suyetno, A., Solichin, \& Wahono. (2019). Pengembangan massive open online courses (MOOCs) pada materi pengelasan. Jurnal Teknik Mesin dan Pembelajaran, 2(2), 141-152. http://doi.org/10.17977/um054v2i2p141-152

You, H. W. (2019), “Students' Perception about Learning using MOOC," Int. J. Emerg. Technol. Learn. IJET, vol. 14, no. 18, pp. 203-208. https://doi.org/10.3991/ijet.v14i18.10802

\author{
Budi Harijanto \\ Department of Technology Information \\ State Polytechnic of Malang, \\ Jl. Soekarno Hatta No.8 Malang, East Java , Indonesia \\ Email: budi.harijanto@polinema.ac.id \\ *Meyti Eka Apriyani (Corresponding Author) \\ Department of Technology Information \\ State Polytechnic of Malang, \\ Jl. Soekarno Hatta No.8 Malang, East Java , Indonesia \\ Email: meytieka@polinema.ac.id
}

\title{
Elok Nur Hamdana
}

Department of Technology Information

State Polytechnic of Malang,

Jl. Soekarno Hatta No.8 Malang, East Java , Indonesia

Email: elokhamdana@polinema.ac.id 